\title{
DECREASE IN THE ELECTROPHORETIC MOBILITY OF RABBIT SPERMATOZOA FOLLOWING INTRA-UTERINE INCUBATION
}

\author{
RAMA A. VAIDYA, R. H. GLASS, PRAMILA DANDEKAR \\ AND K. JOHNSON \\ Departments of Obstetrics \& Gynecology and Biology, \\ rale University School of Medicine, New Haven, Connecticut, U.S.A.
}

(Received 17th September 1970)

Since the introduction of the concept of capacitation, numerous investigators have attempted to define the changes that spermatozoa undergo in the female reproductive tract. Studies utilizing light and electron microscopy have failed to show alterations in sperm structure following incubation in the rabbit uterus for periods up to $15 \mathrm{hr}$, a length of time sufficient to accomplish capacitation (Bedford, 1970). The loss of tetracycline fluorescence from spermatozoa in the oestrous uterus has been suggested as an indicator of capacitation (Ericsson, 1967), but it has since been shown conclusively that this theory can no longer be considered tenable (Vaidya, Bedford, Glass \& Morris, 1969).

Ghanges in the net negative surface charge of rabbit spermatozoa during passage through the epididymis have been demonstrated by micro-electrophoresis (Bedford, 1963). This communication describes changes in the electrophoretic mobility of rabbit spermatozoa after incubation in the oestrous uterus for $6 \mathrm{hr}$, a time sufficient to accomplish partial capacitation.

Seven male animals were used in these experiments and each at different times was used as a donor of intra-uterine and ejaculate spermatozoa. Spermatozoa were flushed with $2 \mathrm{ml}$ of $0 \cdot 145 \mathrm{M}-\mathrm{NaCl}$ solution from the uterus of New Zealand white oestrous does $6 \mathrm{hr}$ after double mating with a fertile buck. The flushings were washed three times in $0.145 \mathrm{~m}-\mathrm{NaCl}$. Following each washing, the spermatozoa were centrifuged at $2000 \mathrm{rev} / \mathrm{min}$ for $10 \mathrm{~min}$ at $4^{\circ} \mathrm{C}$. The spermatozoa were resuspended in $3 \mathrm{ml}$ of a sorbitol phosphate buffer of low ionic strength. The buffer was composed of one part of $19 \mathrm{ml}$ of $0.1 \mathrm{M}-\mathrm{NaH}_{2} \mathrm{PO}_{4}$ and $81 \mathrm{ml}$ of $0.1 \mathrm{M}-\mathrm{Na}_{2} \mathrm{HPO}_{4}$, added to four parts of $5.4 \%$ sorbitol. The $\mathrm{pH}$ of the buffer was 7.4. A portion of an ejaculate was washed and prepared in the same fashion and the spermatozoa suspended in sorbitol phosphate buffer. After washing, the remainder of the ejaculate sample was resuspended in $3 \mathrm{ml}$ of Tyrode's solution and incubated at $37^{\circ} \mathrm{C}$ in a water bath for $6 \mathrm{hr}$. At the end of this time, the spermatozoa were washed twice in $0.145 \mathrm{M}-\mathrm{NaCl}$. Following each washing, they were centrifuged at $2000 \mathrm{rev} / \mathrm{min}$ for $10 \mathrm{~min}$ at $4^{\circ} \mathrm{G}$. The spermatozoa were then resuspended in sorbitol phosphate buffer. All samples were immobilized by cooling to $-4^{\circ} \mathrm{C}$ for $1 \mathrm{hr}$.

The electrophoretic mobility of the spermatozoa was determined in a cylin- 
drical electrophoresis chamber (Rank Bros., Bottisham, Cambridge, England). The thawed samples were diluted to $7 \mathrm{ml}$ with sorbitol phosphate buffer before being placed in the electrophoresis cell. Determinations were made using a voltage gradient of $2 \mathrm{~V} / \mathrm{cm}$ at $24^{\circ} \mathrm{C}$. The electrophoretic mobility at the stationary level was determined by measuring the time required for the sperm head to traverse a distance of $40 \mu$ measured by a graticule in the eye piece (Text-fig. 1). The direction of the current flow was reversed after each reading to minimize electrode effects. Electrophoretic mobility was expressed as microns per second per volt per centimetre $\left(\mu \mathrm{sec}^{-1}\right.$ volt $\left.^{-1} \mathrm{~cm}\right)$.

The spermatozoa incubated in Tyrode's solution had the highest electrophoretic mobility, $1 \cdot 250 \pm 0.018$ (119 observations). Spermatozoa incubated in the oestrous uterus for $6 \mathrm{hr}$ had an electrophoretic mobility of 1.000 \pm 0.010 (114 observations). Ejaculate spermatozoa had an electrophoretic mobility intermediate between the other two groups, $1 \cdot 170 \pm 0 \cdot 013$ (113 observations).

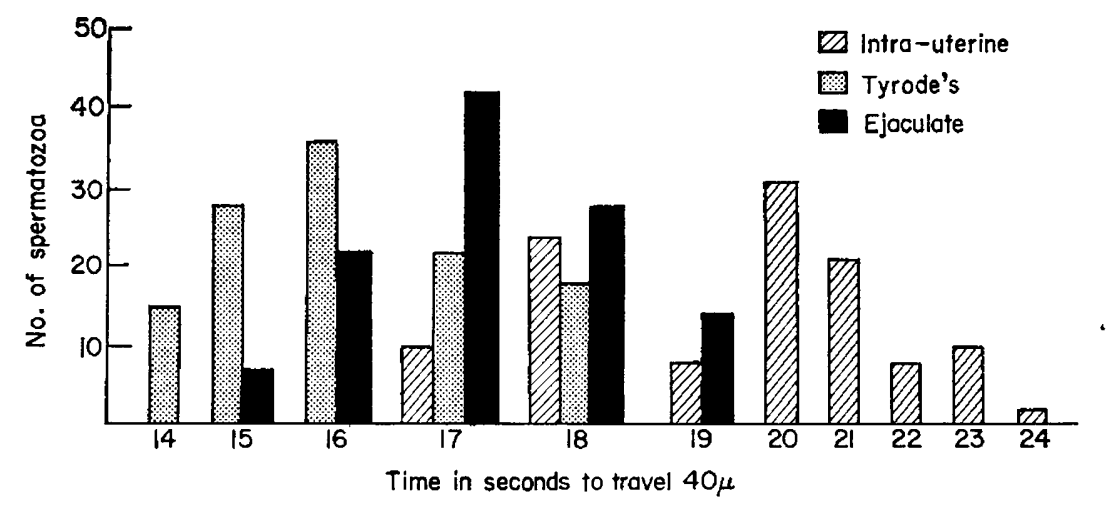

TEXT-FIG. 1. Histogram of rates of migration of ejaculate (17.0 $\pm 0 \cdot 103)$, intra-uterine $(20 \cdot 0 \pm 0 \cdot 168)$ and Tyrode-incubated spermatozoa $(16 \cdot 0 \pm 0 \cdot 111)$.

The difficulties of working with spermatozoa in an electrophoretic field were pointed out by Mudd \& Mudd (1929). The large size of the spermatozoa causes rapid settling out of the focal plane. Usually the tail (with the stronger negative charge) orientates towards the anode and this increases the difficulty of keeping the sperm head in focus. These problems were exaggerated with intra-uterine samples where the number of spermatozoa available was severely limited.

During their passage through the male reproductive tract, spermatozoa remain free of cell to cell contact. Capacitation not only endows the spermatozoa with the competence to penetrate the ovum but also enhances their ability to adhere to the ovum (Bedford, 1967). In addition, uterine leucocytes ingest motile spermatozoa in the oestrous uterus but are unable to do so with intact epidymal or ejaculate spermatozoa (Bedford, 1965). This suggestion of a change in surface characteristics is strengthened by the finding of a decreased electrophoretic mobility of intra-uterine spermatozoa.

A similar significant decrease in the electrophoretic mobility of spermatozoa has been reported after incubation with neuraminadase (Bey, 1965). This enzyme is normally present in the rabbit uterus and it may act to release sialic 
acid from spermatozoa with a resultant reduction in charge density (Hartree \& Srivastava, 1965).

This work was supported by NIH Research Contract No. 69-2098, a grant from the Ford Foundation, and NSF GB 7828.

\section{REFERENCES}

BEDFORD, J. M. (1963) Changes in the electrophoretic properties of rabbit spermatozoa during passage through the epididymis. Nature, Lond. 200, 1178.

BEDFORD, J. M. (1965) Effect of environment on phagocytosis of rabbit spermatozoa. F. Reprod. Fert. 9, 249.

BEDFORD, J. M. (1967) The importance of capacitation for establishing contact between eggs and sperm in the rabbit. F. Reprod. Fert. 13, 365.

BEDFORD, J. M. (1970) Sperm capacitation and fertilization in mammals. Biol. Reprod. Suppl. 2, 128.

BEY, E. (1965) The electrophoretic mobility of sperm cells. In: Cell Electrophoresis, p. 142. Ed. E. J. Ambrose. Little, Brown, Boston.

Ericsson, R. J. (1967) A fluorometric method for measurement of sperm capacitation. Proc. Soc. exp. Biol. Med. 125, 1115.

HaRtree, E. F. \& SRIVAstava, P. N. (1965) Chemical composition of the acrosomes of ram spermatozoa. 7. Reprod. Fert. 9, 47.

Mudd, S. \& MUdD, E. B. H. (1929) The specificity of mammalian spermatozoa with especial reference to electrophoresis as a means of serological differentiation. F. Immun. 17, 39.

Vaidya, R. A., Bedford, J. M., Glass, R. H. \& Morris, J. McL. (1969) Evaluation of the removal of tetracycline fluorescence from spermatozoa as a test for capacitation in the rabbit. $\mathcal{7}$. Reprod. Fert. 19, 483. 